\title{
Usage of biomass CHP for balancing of power grid in Ukraine
}

\author{
Oleksii Epik ${ }^{1, *}$, Vitalii Zubenko ${ }^{1}$ \\ ${ }^{1}$ Institute of Engineering Thermophysics of National Academy of Sciences, Zhelyabova 2a street, \\ 03067, P.O. box 66, Kyiv-67, Ukraine
}

\begin{abstract}
The article contains the first considerations of the problematic of Ukrainian grid balancing issues raised by a rapid increase of RES share in total electricity supply. The provision of balancing electricity with accent on biomass combined heat and power plants (CHP) usage is considered. Three technical concepts are proposed for engaging of existing and planned biomass CHP into balancing operation primary operating in baseload regimes, namely - greenfield biomass thermal power plant (TPP) and CHP working primary in baseload regimes and provide balancing electricity when needed (with and without steam accumulation). It is shown that there are no principle technical limitations for biomass CHP/TPP usage for grid balancing. The levelized cost of electricity (LCOE) of balancing electricity for proposed concepts are calculated and compared with the reference technology proposed by the national grid operator (gas-piston engines and/or gas turbine). According to the calculations performed the LCOE (EUR/MWh) of balancing electricity could be 77-88 EUR/MWh for biomass CHP primary operating in baseload and $216 \mathrm{EUR} / \mathrm{MWh}$ for greenfield biomass TPP against $206 \mathrm{EUR} / \mathrm{MWh}$ for gas-piston/gas-turbine for applied assumptions, prices and tariffs.
\end{abstract}

\section{Introduction}

Electricity generation by renewable energy sources (RES) in Ukraine during 2014-2018 demonstrated dramatic increase (see Fig. 1). According to [1] the essential part of grid electricity as for $1^{\text {st }}$ quarter 2018 is supplied by solar PV (55\%) and wind power (30\%). Total installed capacity of RES-to-grid objects for the $1^{\text {st }}$ quarter of 2018 has already achieved 1.7 GWel with the increment of almost $700 \mathrm{MWel}$ for the last 3 years $[1,2]$. The results of specific sectoral RES-to-power grid modelling for Ukraine [3, 4, 5] demonstrates that such tendency will be continued and the structure of RES-to-power grid supply with dominant role of solar PV and wind power will remain the same till at least 2035.

From the other hand, the national grid operator (dispatcher) - National power company "Ukrenergo" in their own comprehensive research [6] stipulates that "...present power grid balancing facilities (mainly large-scale coal-fired TPPs and at some extent large scale hydropower plants (HPPs) and hydro-accumulation power plants (HAPPs)) allows addition of installed capacity of non-stable RES-to-grid generation on the level of no more than $3 \mathrm{GW}_{\mathrm{el}}$ ".

\footnotetext{
* Corresponding author: epik@,biomass.kiev.ua
} 
In other words, additional $0.7 \mathrm{GW}_{\mathrm{el}}\left(2.3 \mathrm{GW}_{\mathrm{el}}\right.$ is already in the grid) of additional unstable power sources may be considered as critical of Ukrainian grid balance. Bearing in mind also the observed tendencies and mentioned results of dependent modelling forecasts, this figure may be achieved between 2020 and 2021. According to NPC "Ukrenergo", the excess of the $3 \mathrm{GW}_{\mathrm{el}}$ threshold will result in "...the non-regime frequency fluctuations and consequent rapid growth of the risk of grid failures and disbalance of the whole integrated power system" [6]. The only solving of this potential problem currently proposed by NPC "Ukrenergo" is to build up new gas-fired power facilities (based on gas-piston and gas turbine technology) which are technically most suitable for balancing operation due fast response time on the request of grid balancing operator.

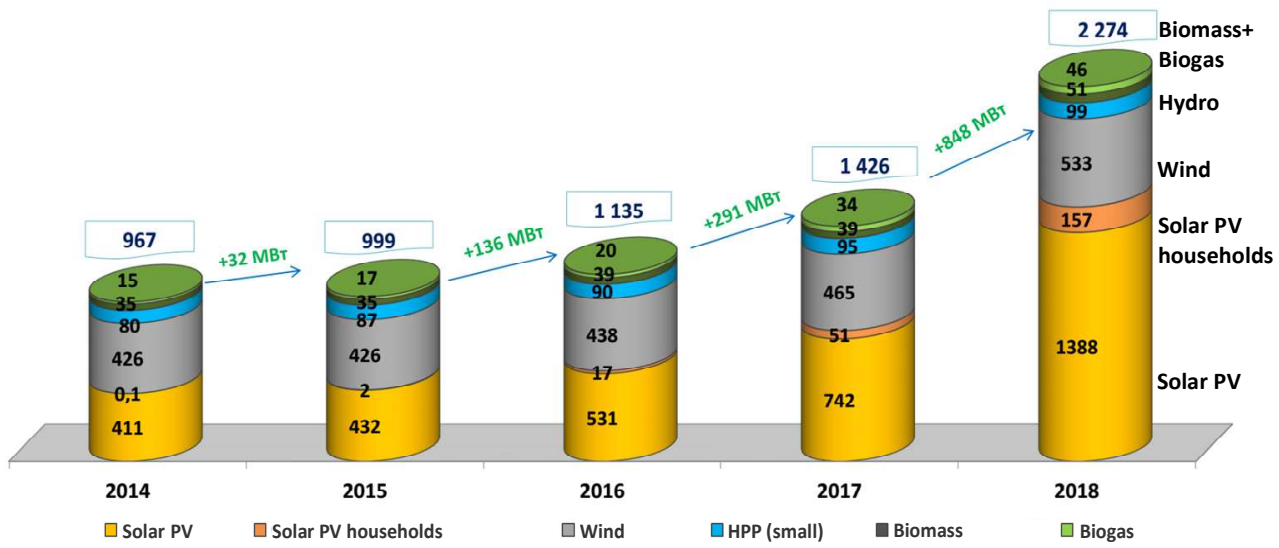

Fig. 1. Evolution of installed capacities from all RES types in Ukraine, 2014-2018, $\mathrm{MW}_{\mathrm{el}}$

However, for the past 20 years there were no case and no publicly announced plans by any active investor or Ukrainian government for building up new gas-to-power units in Ukraine. Moreover, existing gas-fired CHP operated in big cities mainly for heating purposes can't compete with other sources on electricity market, which is confirmed by the recently adopted special Resolution of Parliament \# 324 dated 18 April 2018 [7] aimed on direct financial support of gas-fired CHP to let them survive on the new electricity market otherwise there is a risk of switch from cogeneration operation to the heat-only operation.

The alternative approach for grid balancing could imply use of biomass/biogas CHP/TPP. These facilities are actively implemented in Ukraine since 2015 when key problematic issues has been finally regulated in the newly approved Law on "green" tariff \# 514-VIII [8] along with solar PV and wind power-to-grid generation facilities. As for the 31 December 2018 more than $46 \mathrm{MW}_{\mathrm{el}}$ of solid biomass power-to-grid capacities have been put into operation (see Table 1).

Table 1. The list of implemented solid biomass CHPs/TPPs in Ukraine

\begin{tabular}{|l|l|l|l|l|l|c|}
\hline$\#$ & Name of CHP, & Fuel used & Sector & \multicolumn{2}{|c|}{ Capacity } & $\begin{array}{c}\text { Comis- } \\
\text { sioned } \\
\text { since }\end{array}$ \\
\cline { 5 - 6 } & & & & $\mathrm{MW}_{\mathrm{el}}$ & $\mathrm{MW}_{\text {th }}$ & 2006 \\
\hline 2 & "Kirovogradoliya", PJSC & sunflower husk & Industry & 1,7 & 33 & 2010 \\
\hline 3 & $\begin{array}{l}\text { "Smilaenergopromtrans", } \\
\text { LLC, Smliyanska CHP }\end{array}$ & wood chips & $\begin{array}{l}\text { District } \\
\text { heating }\end{array}$ & 8,5 & 40 & 2012 \\
\hline 4 & "Bombinat Kargill", LLC & sunflower husk & Industry & 2 & 20 & 2013 \\
\hline
\end{tabular}




\begin{tabular}{|l|l|l|l|l|l|c|}
\hline 5 & $\begin{array}{l}\text { Agroholding "Yevgroyl", } \\
\text { LLC } \\
\text { Mykolaiv CHP }\end{array}$ & sunflower husk & Industry & 5 & 30 & 2013 \\
\hline 6 & $\begin{array}{l}\text { "Clear Energy", LLC } \\
\text { Koryikivka CHP }\end{array}$ & wood chips & Industry & 3,5 & 10 & 2016 \\
\hline 7 & Rakhiv CHP & wood chips & $\begin{array}{l}\text { District } \\
\text { heating }\end{array}$ & 6.0 & 10 & $10 / 2017$ \\
\hline 8 & "SINGA ENERGIES", LLC & sunflower husk & Industry & 5,12 & 25 & $04 / 2018$ \\
\hline 9 & $\begin{array}{l}\text { "Kriger" LLC, Kamyanetsk } \\
\text { ORC CHP }\end{array}$ & $\begin{array}{l}\text { wood chips, } \\
\text { pellets, straw }\end{array}$ & $\begin{array}{l}\text { District } \\
\text { heating }\end{array}$ & 1,2 & 40 & $07 / 2018$ \\
\hline 10 & $\begin{array}{l}\text { "Yougenergo", LLC } \\
\text { Pereysalav CHP }\end{array}$ & wood chips & $\begin{array}{l}\text { District } \\
\text { heating }\end{array}$ & 5 & 12 & $09 / 2018$ \\
\hline 11 & $\begin{array}{l}\text { Mebel-service, LLC, } \\
\text { Radekhiv CHP (furniture) }\end{array}$ & wood chips/dust & Industry & 2,2 & 10 & $09 / 2018$ \\
\hline & TOTAL CAPACITY & & $46(58)$ & 230 & \\
\hline
\end{tabular}

Additionally there are dozens of publicly available biomass CHP projects announced by investors, some of them already on commissioning stage. According to National Commission of Electricity Regulation of Ukraine (NERC), more than 20 biomass CHP/TPP projects are currently on different implementation stages and are to be commissioned in 2019-2021 [9] increasing total installed capacity to $200-250 \mathrm{MW}_{\mathrm{el}}$. These facilities are focused on baseload electricity-to-grid supply by "green" tariff, some of them working in cogeneration regime.

The latest state-level programmatic documents like Energy Strategy-2035 (2017) [10], National Renewable Energy Action Plan (NREAP-2020) (2014) [11], Plan of actions for Energy Strategy-2035 (2018) [12] also consider substantial growth of biomass/biogas CHP/TPP input in total energy balance of Ukraine. For example, the Energy Strategy till 2035 foresees increasing of primary energy supply from biomass to 11 Mtoe in 2035. This means also the increasing of installed capacity of solid biomass CHPs/TPPs to at least $1.7 \mathrm{GW}_{\mathrm{el}}$ in 2035 [13]. NREAP-2020 contains the figure of $660 \mathrm{MW}_{\mathrm{el}}$ of solid biomass and biogas power capacities in 2020 . Some portion of these capacities may be engaged not only in baseload operation but also in balancing operation.

At the same time, in Ukraine, despite the number of comprehensive public debates and available researches on grid balancing with large shares of unstable power-to-grid sources, the engagement of biomass/biogas technologies for these purposes has not yet been considered by somebody. So, there is a mature necessity to start considering these issues. The purpose of this article is to at least raise the problematics, drafting first assumptions for viable concepts of biomass-to-grid facilities usage for grid balancing in Ukraine.

\section{Concept of technical realization and key assumptions}

Biomass CHPs/TPPs are commonly considered as baseload capacities with low maneuvering possibilities, characterized by slow response rate on the request of grid operator for changing of power capacity. The typical biomass CHP in Ukraine and the EU-28 is operating in industrial or district heating sector with main purpose of baseload heat supply. The installed power capacity of typical biomass CHP/TPP is most commonly in range of 3-10 $\mathrm{MW}_{\mathrm{el}}$, often defined by the respective heat loads. There are only a few examples of biomass CHPs in the EU-28 with capacities more than $20 \mathrm{MW}_{\mathrm{el}}$ working in power-only generation regime [14].

On practice in the EU-28 and other countries, biomass CHP and TPP are actively used for grid balancing. The typical concepts of their engagement are different, and could be summarized as follows $[14,15,16]$ : 
1) Large-scale ( $>200 \mathrm{MW}_{\mathrm{el}}$ ) existing fossil fuel (usually coal) TPP units with biomass co-firing (share of biomass 5-40\%, most common 10\%);

2) Large-scale $\left(>30 \mathrm{MW}_{\mathrm{el}}\right)$ biomass-only TPPs;

3) Medium-scale (3-10 MWel) biomass-only TPPs/CHPs (industrial and district heating);

4) IGCC installations with biomass co-firing;

5) Biogas CHPs based on gas-piston and gas-turbine generation technologies

6) Usage of biomethane;

7) In perspective, medium-scale (5-15 $\mathrm{MW}_{\mathrm{el}}$ ) power plants on II-nd III-rd generation of liquid biofuels (for example bio-oil);

Biomass-to-power facilities are implemented in the vast majority of cases not for the purpose of balancing, but as baseload facilities aimed on gaining profits through electricity, heat and (in some cases) cold supply. Their operation in balancing regimes may be considered as bonus activities only, opposite to the specially designed maneuvering natural gas balancing capacities. It is extremely important to understand that main purpose of existing or planned biomass CHP/TPP in Ukraine and abroad is baseload operation, not balancing. That is why it is necessary to consider balancing operation regimes as supplementary to the permanent, primary activity of biomass facilities.

Another issue is the ratio between balancing capacities and capacities of unstable gridconnected facilities, "balancing MWel/unstable MWel". There are different views on this factor, it can vary in the range of $0.1 \ldots 2.0[14,15,16]$. According to the NPC "Ukrenergo" each grid-connected Megawatt of unstable power sources shall be supported by same equivalent grid-connected Megawatt of balancing generation [6].

For the purpose of current work, the biomass CHP concept considered is based on steam Ranking cycle with condensing turbine. It is the most commercially sound technology for power generation from solid biomass in Ukraine proved by implemented (10 out of 11 are based on this technology) and planned projects as well as practical experience of the EU-28 and other countries. Power output capacity is taken as $10 \mathrm{MWel}$ (on generator), respective heat capacity of the boiler is $40 \mathrm{MWel}, 30 \mathrm{MWth}$ is coming to condenser. These parameters are chosen as they are typical for medium-scale biomass CHPs in Ukraine. The reference case is gas-fired piston engines or gas turbine with the same power capacity according to views of NPC "Ukrenergo" which technically have fastest response time on power capacity increasing/decreasing request among other technologies and thus most suitable for the balancing operation regimes (progressing from cold state to the nominal capacity during 30 $\sec -5 \min [6,17,18,19])$.

As the Concept \#1 let's consider the greenfield biomass TPP based on the steam Ranking cycle with condensing turbine (see the simplified principal scheme at Fig. 2).

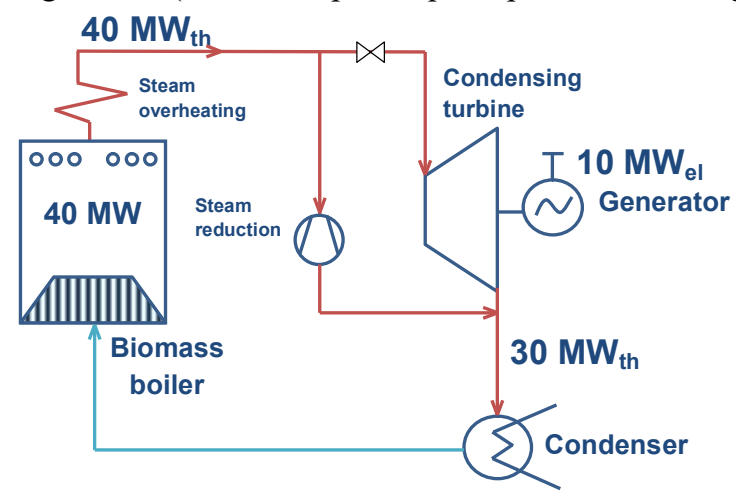

Fig. 2. Principal scheme of greenfield biomass TPP with condensing steam Ranking cycle used only for grid balancing (Concept \# 1). 
Such installation could technically operate in both baseload and balancing regimes $(7,600$ and 1,000 hours respectively). 1,000 hours are chosen according to daily operation on peak load for maximum 2.5-3 hours and corresponds to the daily peak load requested by the grid operator according to average summer/winter daily power graph of the Ukrainian power grid [20]. Further concepts will be based on Concept \#1 supplemented with additional technical modifications.

\section{Methodology and input data}

With purpose to compare different technologies the common Levelized Cost of Electricity (LCOE) factor is used [21].

$$
L C O E=\frac{\sum_{i=1}^{n} \frac{C A P E X_{i}+O P E X_{i}}{(1+r)^{i}}}{\sum_{i=1}^{n} \frac{E_{i}}{(1+r)^{i}}},
$$

where:

CAPEX $X_{i}$ - Total capital cost of technology in the year $i$;

$O P E X_{i}$ - Total operational cost of technology in the year $i$;

$E_{i}$ - useful electricity output in the year $i$;

$r$-discount rate. For the purpose of the calculation equals zero;

$n$-project lifetime, years. For the purpose of the calculation equals 25 years.

$$
O P E X_{i}=F_{i}+M_{i}+W_{i}+C_{i},
$$

where:

$F_{i}$ - cost of fuel in the year $i$;

$M_{i}$ - cost of maintenance and materials in the year $i$;

$W_{i}$ - cost of workforce in the year $i$;

$C_{i}-$ cost of contingency in the year $i$.

The input data used for the calculation is presented in Table 2:

Table 2. Input data for the calculation

\begin{tabular}{|l|l|l|}
\hline Parameter & Value & Unit \\
\hline Power capacity of CHP/TPP & 10 & $\mathrm{MW}_{\mathrm{el}}$ \\
\hline Operational hours for balancing regime & 1,000 & hours/year \\
\hline Operational hours for baseload regime & 7,600 & hours/year \\
\hline Specific cost of biomass CHP/TPP [22] & 3,000 & $\mathrm{EUR} / \mathrm{kW}_{\mathrm{el}}$ installed \\
\hline $\begin{array}{l}\text { Specific cost of gas-fired piston engine/gas turbine } \\
{[23]}\end{array}$ & 1,000 & $\mathrm{EUR} / \mathrm{kW}_{\mathrm{el}}$ installed \\
\hline NCV of biomass & 12 & $\mathrm{MJ} / \mathrm{kg}$ \\
\hline NCV of natural gas & 33 & $\mathrm{MJ} / \mathrm{m}^{3}$ \\
\hline Cost of biomass w/o VAT & 30 & $\mathrm{EUR} / \mathrm{t}$ \\
\hline Cost of natural gas w/o VAT [24] & 300 & $\mathrm{EUR} / 1000 \mathrm{~m}^{3}$ \\
\hline $\begin{array}{l}\text { Average weighted operational electric efficiency of } \\
\text { biomass CHP/TPP }\end{array}$ & $25 \%$ & $\%$ \\
\hline $\begin{array}{l}\text { Average weighted operational electric efficiency of } \\
\text { gas-fired piston engine/gas turbine CHP/TPP }\end{array}$ & $30 \%$ & $\%$ \\
\hline
\end{tabular}




\section{Main results and discussion}

At first iteration it is necessary to calculate LCOE for the Concept \# 1 - greenfield biomass TPP specifically designed and constructed exclusively for grid balancing.

According to the applied assumptions and performed calculations, the LCOE of balancing electricity for the Concept \# 1 is $216.4 \mathrm{EUR} / \mathrm{MWh}$, which is much higher than current wholesale electricity tariff in Ukraine (70 EUR/MWh) and "green" tariff (123.9 EUR/MWh). The respective LCOE for baseload generation of the Concept \#1 is $63.4 \mathrm{EUR} / \mathrm{MWh}$. For the reference case, LCOE for balancing electricity is $206.4 \mathrm{EUR} / \mathrm{MWh}$ (bearing in mind 300 EUR $/ 1000 \mathrm{~m}^{3}$ natural gas price which is quite conservative and may be much higher depending on the region of Ukraine) and 139.4 EUR/MWh of baseload generation (see Table 3).

Table 3. LCOE of balancing electricity and baseload electricity for Concept \# 1 and for the reference case - gas piston engine/gas turbine TPP

\begin{tabular}{|l|l|l|l|l|l|l|}
\hline $\begin{array}{l}\text { Technology/ } \\
\text { Operation } \\
\text { regime }\end{array}$ & $\begin{array}{l}\text { CAPEX, } \\
10^{3} * \text { EUR } \\
\text { (lifetime) }\end{array}$ & $\begin{array}{l}\text { MWhel } \\
\text { year }\end{array}$ & $\begin{array}{l}\text { Fuel, t } \\
\text { or } \\
10^{3} * \mathrm{~m}^{3}\end{array}$ & $\begin{array}{l}\text { Fuel cost } \\
\text { annual, } \\
10^{3} * \mathrm{EUR}\end{array}$ & $\begin{array}{l}\text { Maintenance, } \\
\text { materials, } \\
\text { workforce, } \\
\text { other } \\
\text { contingency, } \\
\text { EUR }\end{array}$ & $\begin{array}{l}\text { LCOE, } \\
\text { EUR/ } \\
\text { MWh }\end{array}$ \\
\hline $\begin{array}{l}\text { Biomass TPP } \\
\text { baseload }\end{array}$ & 30,000 & 76,000 & 91,200 & 2,736 & 886,000 & 63.4 \\
\hline $\begin{array}{l}\text { Biomass TPP } \\
\text { balancing }\end{array}$ & 30,000 & 10,000 & 14,500 & 435 & 529,425 & 216.4 \\
\hline $\begin{array}{l}\text { Gas fired TPP } \\
\text { baseload }\end{array}$ & 10,000 & 76,000 & 27,636 & 8,290 & $1,903,891$ & 139.4 \\
\hline $\begin{array}{l}\text { Gas fired TPP } \\
\text { balancing }\end{array}$ & 10,000 & 10,000 & 4,136 & 1,240 & 423,390 & 206.4 \\
\hline
\end{tabular}

Obviously, such high indicators of LCOE for balancing electricity means that Concept \# 1 is not viable in balancing operation regime for current market conditions. Thus, there is a necessity to search a ways for decreasing of LCOE for biomass TPPs operating in balancing regimes.

One of the possible solutions is to partly engage in balancing operation regimes existing biomass CHPs or those designed for purposes other than balancing - Concept \#2 (see Fig. 3). In this case, CHP is partly engaged into balancing operation by enhancing of electric installed capacity of condensing turbine to the level required by both balancing and baseload operation regimes. For the strict comparison with Concept \#1, let's consider the same input heat and output power capacity levels but divide them between baseload operation and balancing operation. Also, the very important feature is that this is CHP working in cogeneration regime providing useful heat (in our example, for industrial purposes (see Fig. 3)). The principal scheme for this updated Concept \#2 consists of 2 boilers $20 \mathrm{MW}_{\text {th }}$ each and condensing steam turbine with extraction (to provide steam technological needs) with the same installed power capacity as for Concept \#1 (10 MW $\left.\mathrm{MW}_{\mathrm{el}}\right)$. However, in Concept \#2 the baseload capacity is 6 $\mathrm{MW}_{\mathrm{el}}$. Another part $-4 \mathrm{MW}_{\mathrm{el}}$ - is "reserved" for balancing operation regime only. The appropriate heat load for technological needs is adjusted in such a way that $6 \mathrm{MW}_{\mathrm{el}}$ baseload capacity on nominal is enough to provide $100 \%$ of these needs. $4 \mathrm{MW}_{\mathrm{el}}$ of balancing capacity is engaged only when needed ( 3 hours per day on nominal or 1,000 hours per year). 2 boilers of $20 \mathrm{MW}_{\text {th }}$ each are specially designed to make regulation of the whole cycle more effective and to maximize the capacity factor $(60-70 \%$ in baseload for each boiler). 


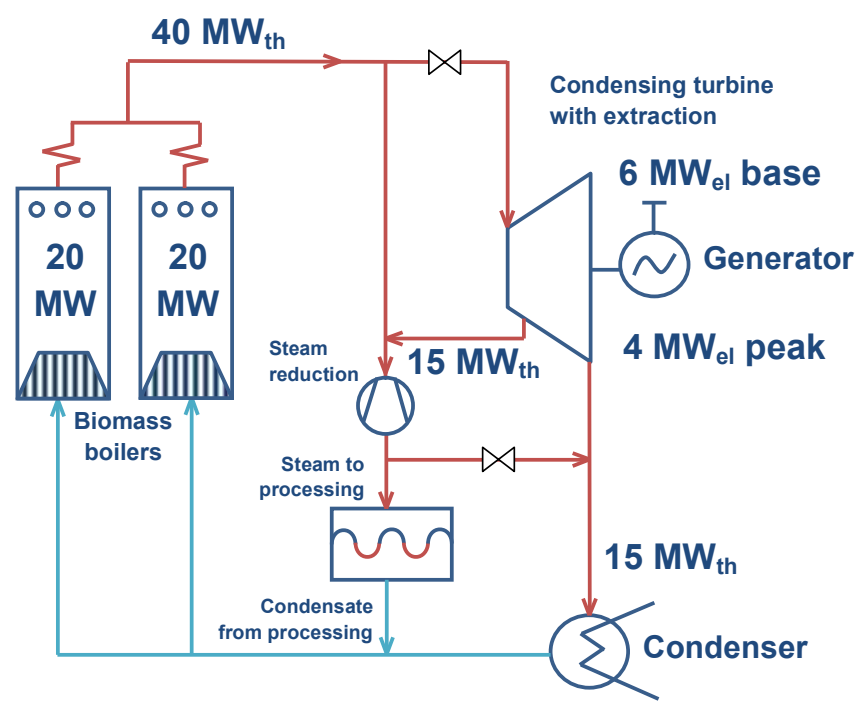

Fig. 3. Principal scheme of biomass CHP primary aimed for baseload operation and partly engaged for grid balancing (Concept \# 2)

The calculation shows that for Concept \#2, LCOE for baseload generation is on the level of 58.8 EUR/MWh. This figure is obtained for the case when all CAPEX and workforce associated with both baseload and balancing operation regimes are attributed to baseload operational regime only. In this case, according to the calculation, LCOE for biomass CHP baseload will be 58.8 EUR/MWh and the LCOE for balancing electricity from same biomass CHP will be 86.4 EUR/MWh.

Table 4. LCOE of balancing electricity for Concept \#2

\begin{tabular}{|l|l|l|l|l|l|l|}
\hline $\begin{array}{l}\text { Operation } \\
\text { regime }\end{array}$ & $\begin{array}{l}\text { CAPEX, } \\
10^{3} * \mathrm{EUR} \\
\text { (lifetime) }\end{array}$ & $\begin{array}{l}\frac{\mathrm{MWh}_{\text {le }}}{\mathrm{MWh}_{\text {th }} /} \\
\text { year }\end{array}$ & Fuel, t & $\begin{array}{l}\text { Fuel cost } \\
\text { annual, } \\
10^{3} * \text { EUR }\end{array}$ & $\begin{array}{l}\text { Maintenance, } \\
\text { materials, } \\
\text { workforce, } \\
\text { other } \\
\text { contingency, } \\
\text { EUR }\end{array}$ & $\begin{array}{l}\text { LCOE, EUR/ } \\
\text { MWh }\end{array}$ \\
\hline $\begin{array}{l}\text { Biomass CHP } \\
\text { baseload }\end{array}$ & 18,000 & $\frac{45,600}{114,000}$ & 107,335 & 3,220 & 842,310 & 58.8 \\
\hline $\begin{array}{l}\text { Biomass CHP } \\
\text { balancing }\end{array}$ & 12,000 & 4,000 & 6,161 & 184.8 & 160,646 & 86.4 \\
\hline
\end{tabular}

For both Concepts \#1 and \# 2, the regime of dynamic increasing/decreasing of power capacity include the lag between response time required by grid balancing operator (delivery of necessary power in 30 seconds-15 minutes, depending on the reserve class of the installation, most usual is 5-10 minutes $[6,17])$ and actual response time depending to maneuver possibilities of the solid biofuel installation to run from zero capacity to nominal (30 minutes -2 hours, usually 1 hour $[25,26]$ ).

To make the cycle more efficient, the Concept \#3 has been developed (Fig. 4). It is similar to Concept \#2, the only new feature is addition of steam storage tank aimed on accumulation of steam (heat) during baseload and during acceleration/ deceleration of biomass boilers. For current scheme, the installed capacity of such a tank is $10 \mathrm{MW}_{\text {th }}$ and the volume is calculated according to [27] as $170 \mathrm{~m}^{3}$. 


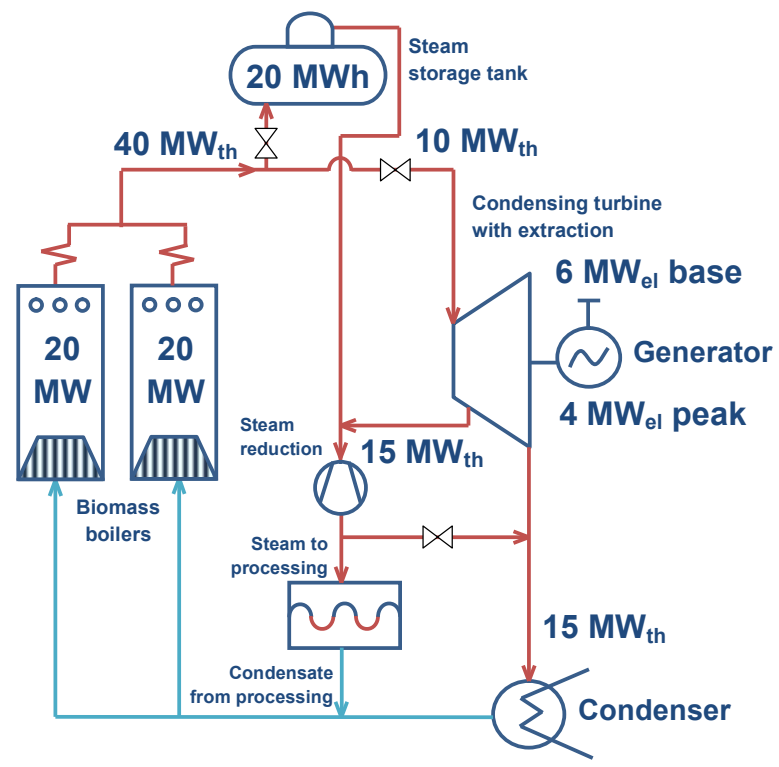

Fig. 4. Principal scheme of biomass CHP with steam accumulation primary aimed for baseload operation and partly engaged for grid balancing (Concept \#3)

The calculation of LCOE for the Concept \#3 shows that installation of steam storage tank may decrease it to $77.9 \mathrm{EUR} / \mathrm{MWh}$ with the conservatively estimated cost of such equipment (including all auxiliary, integration to the cycle and other contingency cost) of 1.2 million EUR.

Table 5. LCOE of "balancing electricity" for Concept \# 3

\begin{tabular}{|c|c|c|c|c|c|c|}
\hline $\begin{array}{l}\text { Operation } \\
\text { regime }\end{array}$ & $\begin{array}{l}\text { CAPEX, } \\
10^{3}{ }^{*} \text { EUR } \\
\text { (lifetime) }\end{array}$ & $\begin{array}{l}\frac{\mathrm{MWh}_{\mathrm{el}}}{\mathrm{MWh}_{\mathrm{th}} /} \\
\text { year }\end{array}$ & Fuel, t & $\begin{array}{l}\text { Fuel cost } \\
\text { annual, } \\
\text { EUR }\end{array}$ & $\begin{array}{l}\text { Maintenance, } \\
\text { materials, } \\
\text { workforce, } \\
\text { other } \\
\text { contingency, } \\
\text { EUR }\end{array}$ & $\begin{array}{l}\text { LCOE, } \\
\text { EUR/ } \\
\text { MWh }\end{array}$ \\
\hline $\begin{array}{l}\text { Biomass CHP } \\
\text { balancing }\end{array}$ & 13,200 & 4,000 & 4,800 & 144,000 & 167,520 & 77.9 \\
\hline
\end{tabular}

With such indicators, electricity from biomass CHP operating in both baseload and balancing regimes could compete with other technologies on the balancing market (and reserve market), as the LCOE of balancing electricity is slightly higher than current wholesale electricity tariff in Ukrainian grid.

According to Table 6, which summarizes all analyzed scenarios, the lowest LCOE of balancing electricity is for the option "Biomass CHP with steam accumulation" and the highest LCOE is for both - biomass greenfield TPP or gas-fired TPP.

Table 6. LCOE for all concepts considered and gas-fired TPP as reference case

\begin{tabular}{|l|l|}
\hline Technology/ Operation regime & LCOE, EUR/MWh(el) \\
\hline Biomass TPP baseload & 63.4 \\
\hline Biomass TPP balancing & 216.4 \\
\hline Gas fired TPP baseload & 139.4 \\
\hline Gas fired TPP balancing & 206.4 \\
\hline
\end{tabular}




\begin{tabular}{|l|l|}
\hline Biomass CHP baseload & 58.8 \\
\hline Biomass CHP balancing without steam accumulation & 86.4 \\
\hline Biomass CHP balancing with steam accumulation & 77.9 \\
\hline
\end{tabular}

\section{Conclusions}

1) The gas-fired piston-engine based balancing facilities could be used for balancing purposes but are not the only alternative for coverage of non-balance peaks caused by fast RES share increasing in power system of Ukraine;

2) Usage of greenfield biomass TPP for grid balancing based on steam Ranking cycle (primary aimed for grid balancing only) have the LCOE of "balancing electricity" of $216 \mathrm{EUR} / \mathrm{MWh}_{\mathrm{el}}$, which is equal or slightly higher than for gas-fired balancing facilities (206 EUR/MWh $\mathrm{el}_{\mathrm{el}}$ ) in current fuel prices;

3) Usage of biomass CHP based on steam Ranking cycle primary aimed for baseload operation (including existing ones) and modified for grid balancing have much lower

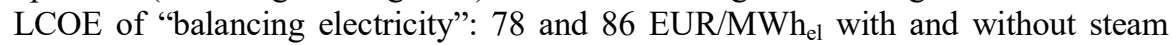
accumulation respectively;

4) For open electricity market starting from 1 July 2019 in Ukraine, there are no technical and economic barriers for the baseload biomass CHPs to partly operate as balancing facilities equally competing with other balancing electricity sources.

\section{References}

1. State Agency of Energy Efficiency and Energy Saving, Official issue, 2018. http://saee.gov.ua/sites/default/files/PR_EE_RE_4_years_30_08_2018.pdf

2. Ukrainian Association of Renewable Energy, Enhancing of RES production in Ukraine. Official newsletter, 2018.

3. O. Diachuk, M. Shepelev. R. Podolets, Yu. Oharenko at all., Transition of Ukrainian Energy Sector to $100 \%$ of RES till 2050. Issued by: Heinrich Boll Fund in Ukraine, Institute of Economics and Forecasting of NASU, 2017.

4. O. Tryboi, A. Epik, G. Boye Olsen et all., Transition of Ukrainian energy sector towards $100 \%$ RES in 2050. International project ASET, NGO "REA", INFORSEEurope, 2017.

5. M. Child, D. Bogdanov et. all. Transition towards a $100 \%$ Renewable Energy System by 2050 for Ukraine. Issued by Lappeenranta University of Technology, 2016.

http://www.neocarbonenergy.fi/wp-content/uploads/2016/02/3_Child.pdf

6. Report of NPC "Ukrenergo" On Estimation of Necessity (Adequacy) of Generation Capacities, 2017.

https://ua.energy/wp-content/uploads/2017/10/Zvit-z-otsinky-vidpovidnostidostatnosti-generuyuchyh-potuzhnostej.pdf

7. Resolution of CMU \# 324 "On Approval of the Temporary Support Provision for the Producers Performing Combined Heat and Power Production on CHP" as of 18 October 2018 (approved) http://zakon2.rada.gov.ua/laws/show/324-2018-\%D0\%BF

8. Law of Ukraine on Amendments to Regulations for Provision of Competitive Conditions of Electricity Generation from Alternative Energy Sources, 2015. http://zakon0.rada.gov.ua/laws/show/514-19

9. Registry of Power Generation Objects on Alternative Energy Sources by National Commission on Electricity Regulation of Ukraine, as for 1 October 2018: 
http://www.nerc.gov.ua/data/filearch/litsenziini_reestry/REESTR_ALT.pdf

10. New Energy Strategy till 2035 "Efficiency, Security, Competiveness" (in effect, 18 August 2017):

http://mpe.kmu.gov.ua/minugol/control/uk/publish/article?art_id=245230270\&cat i $\mathrm{d}=35109$

11. National Renewable Energy Action Plan of Ukraine till 2020 (in effect, 2014) http://saee.gov.ua/documents/NpdVE eng.pdf

12. Plan of Measures for Energy Strategy of Ukraine till 2035 (in effect, 6 June 2018) https://www.kmu.gov.ua/ua/npas/pro-zatverdzhennya-planu-zahodiv-z-realizaciyietapu-reformuvannya-energetichnogo-sektoru-do-2020-roku-energetichnoyistrategiyi-ukrayini-na-period-do-2035-roku-bezpeka-energoefektivnistkonkurentospromozhnist

13. A. Epik V. Zubenko, Forecast of heating sector transition to biomass-based generation till 2050. Proceedings of International Conference "World Sustainable Energy Days-2018”, 28 February - 2 March 2013, Linz-Wels, Austria, 2018.

14. A. Arasto, D. Chiaramonti, J. Kiviluoma, et all., Bioenergy's role in balancing the electricity grid and providing storage options - an EU perspective. Published by IEA Bioenergy: Task 41, $P 6$ (2017).

15. Renewable Energy Integration in Power Grids. Published by ETSAP-IRENA. 2015. http://www.irena.org/publications/2015/Oct/Renewable-energy-integration-inpower-grids

16. Integrating Renewable Electricity on the Grid. A Report by the APS Panel on Public Affairs. American Physical Society.

https://www.aps.org/policy/reports/popa-reports/upload/integratingelec.pdf

17. Technical Requirements of response time of balancing capacities by Fingrid https://www.fingrid.fi/en/electricity-market/reserves_and_balancing/frequencycontainment-reserves/

18. Integration of solar and wind power capacities into the Ukrainian power grid. Presentation of NPC "Ukrenergo", 2018.

https://www.slideshare.net/Ukrenergo/ss-92759300

19. Problematic issues of power-to-grid production by RES in Ukraine. Presentation of NPC "Ukrenergo", 2018.

https://www.slideshare.net/Ukrenergo/ss-90511879

20. Daily graphs of power grid operation in Ukraine

https://ua.energy/diyalnist/dyspetcherska-informatsiya/dobovyj-grafik-vyrobnytstvaspozhyvannya-e-e/

21. LCOE methodology by EIA

https://www.eia.gov/outlooks/aeo/pdf/electricity_generation.pdf

22. Renewable power generation costs in 2017. Published by IRENA. ISBN 978-929260-040-2, 2018.

23. Energy technology perspectives 2017. Pathways to a clean energy system. International Energy Agency, ISBN: 978-92-64-27597-3, 2017.

24. The tariff for end customers for Kyivgas as for 1 October 2018 https://energy.kyivgaz.ua/ofitsijna-informatsiya/tsini-ta-tarifi-na-gaz.html

25. V. Kovetsky M. Kovetskaya. Estimation of maneuver possibilities of power generation technologies for provision of proper electricity quality in the grid. System researches and complex problems of energy, 16 (2007).

26. Maneuver possibilities of different technologies http://energetika.in.ua/ru/books/book-3/part-2/section-2/2-8

27. M. Gurevych, P. Fedorov, Heat and power facilities of sugar industry. Published by State Publishing House of Technical Literature of USSR, 1962. 